\title{
INFLUENCE OF REHABLLITATION ON HEALTH OF BALLROOM DANCERS AFTER SPORTS INJURIES
}

\author{
Adrianna Banio \\ Faculty of Physical Culture and Health Promotion, University of Szczecin, Poland \\ Address for corpespondence: \\ Adrianna Banio \\ University of Szczecin, Faculty of Physical Education and Health Promotion \\ Al. Piastów 40B, building 6, 71-065 Szczecin, Poland \\ E-mail: adrianna.banio@wp.pl
}

Ahstract. The paper is aimed at assessing the influence of rehabilitation on health of ballroom dancers after sports injuries.

At the turn of 2014 and 2015 ballroom dancers from all around Poland were questioned. The surveyed were professional dancers aged between 13 and 30 years. As many as 63 athletes were injured during their career. The rehabilitation of 47 of them took place in the rehabilitation centre under physiotherapeutic supervision. Only 16 of the injured rehabilitated on their own.

The opinion poll based on the survey was used as a method. The questionnaire included closed and open questions which were to show the influence of injury and its treatment on future sports career. Questions were detailed and referred to the kinds of injuries and their causes, the process of treatment, duration of rehabilitation, its process and results. Questionnaire results were analysed statistically with the use of the Pearson's chi-squared test.

It has been proved that rehabilitation under physiotherapeutic supervision has positive influence on health of ballroom dancers after injuries. Specialist rehabilitation of sportsmen after sports injuries contributed to the shortening of time of the recuperation and to the complete recovery. The time of recovery of the injured who did not undergo the professional rehabilitation was longer, and it was impossible to restore lost functions in the group of $5 \%$ of the surveyed, which resulted in the end of their career.

Dancers after sports injures should always undergo professional rehabilitation under the sports doctor's and physiotherapist's supervision.

Key WOrlls: dance, ballroom dance, latin dance, sports injuries, rehabilitation

\section{Introduction}

The aim of rehabilitation of sportsmen who were injured as a result of sport discipline training is re-establishing the correct anatomical and biomechanical bonds in the injured areas and warranting the return to the sports activity from before the injury. The treatment should be multipart and include the correct diagnostics, immediate specialist therapy and periodical rehabilitation. Not only is the complete healing of damaged structures and their functionality restoration desired, but also the endeavour to re-establish the correct static and dynamic activity in full form. 
"Trauma is a kinetic, chemical, thermal factor etc. causing tissue damage. While injury is a damage that is a consequence of trauma" (Kita, 2004, pp. 171-175). The scope of injury depends on the kind and the size of trauma, as well as the resistance of a certain tissue. It is caused by the functional or structural disorders which result from the post-trauma biochemical, ultra-structural and micro- or macroscopic changes. Local traumas can be accompanied by various intensified systemic changes. The intensification of these changes depends not only on the individual system reactivity but also on: strength, direction and the type of trauma, the place and the affected organ. Traumatic injuries of the musculoskeletal system can occur as acute or chronic (primary, secondary) injury. Trauma - that can occur during physical sports activity, and its aftermath which results in the exclusion from training (temporary or complete) - is called a sports injury (Widuchowski, Widuchowski, 2005).

The best and most common scheme of the direct post-traumatic procedure is the PRICEMM rule (Kita, 2004; Gawroński, 1998) (Table 1).

Table 1. Post-traumatic procedure - the PRICEMM rule

\begin{tabular}{l}
\hline PRICEMM rule \\
\hline P - Protection - Support, protection, absolute or relative immobilisation (walking stick, crutch, splint, orthosis, plaster cast, bandage, tape). \\
R - Rest - (reduction of general and local activity). \\
I - Ice - ice, cooling (cold appliance, cryotherapy). \\
C - Compression - (bandage, compression arm sleeves). \\
E - Elevation - (over the heart, supine position, splint, sling). \\
M - Mediciation - pharmacotherapy (NSAIDs and other). \\
M - Modalities - physiotherapy (laser, ultrasounds, electrical stimulation, etc.).
\end{tabular}

There are three phases of healing process (healing of the damaged tissues): acute phase (up to 48 hours), restoration and regeneration phase (from 48 hours up to 6-7 weeks), and the final phase (from 6-8 weeks up to few years). In case of failing to start the treatment, or an improper procedure, the damages may lead to permanent and dangerous dysfunction, not only disabling sports activity but also the daily activity. The treatment can be divided into: operational, preservative, and rehabilitating. The surgical operations aim at restoring the function, activity and the shape of the damaged structures. The preservative treatment includes less invasive surgical treatment (bone set, immobilisation, intra-articular injections, etc.), pharmacotherapy and the elements of rehabilitation. However, rehabilitation (kinesis therapy, physiotherapy, massage) is responsible for the restoration of the joints motion and the muscle strength.

In a complex treatment of injured sportsmen it is essential to take into account various psychological aspects (Olex-Mierzejewska, 1996) which eventually determine the process and the outcome of treatment, and are essential in effective handling of the cognitive, emotional and behavioural consequences of injuries. As J. Heil assumed, injury is a physical and psychological test of strength for a sportsman (Heil, 1993). Undoubtedly, the medical as well as psychological rehabilitation should go together and parallel because various psychosomatic reactions can slow down the restoration process. Therapists can do both: boost the sportsman's perception of the seriousness of the injury, as well as boost the trust in the effectiveness of treatment and the benefits of performing arranged exercises and rehabilitation (Kłodecka-Różalska, 1996). It is known that the sportsman's carrier does not last forever but the worst happens when it ends because of the injury. Sometimes, seemingly not dangerous injury "[...] may annihilate 
the several months' labour and deprive the sportsman of the possibility of achieving a life success. The medical personnel should respect the athlete's goals. Occasionally, the doctor should protect the sportsman against himself, as well as the society's pressure" (Blecharz, 2009, p. 86). Unfortunately, at times, getting back in shape, from before the injury, is impossible. Therefore the question is: what's next? Thanks to the gained psychological abilities, sportsmen can regain the self-esteem, as well as the complete satisfaction from the way they function and they can prepare more effectively to start a new way.

Small number of sportsmen who are not medically treated show how high is the dancers' awareness. They know, very well, the mechanisms of injuries and the significance of a swift introduction of rehabilitation (Wanke, Quarcoo, Uibel, Groneberg, 2012). They also know which symptoms they should pay attention to and they understand that, in spite of the proper orthopaedic, traumatic or neurological treatment, the disregard of rehabilitation may lead to the disruption or the early end of their sport's career. Sportsmen's motivation to cure the injury is of twofold importance (Wanke et al., 2013) because their main goal is not to achieve a state from before the trauma but to achieve the ability of getting back to intensive training as quickly as possible. In ballroom dancing, apart from the public pressure, the strong incentive is the co-dancer, whom the injury burden affects the most. That is why they expect the fastest recovery of the strength and agility. The desire to get back on the floor results in reliable fulfilment of the doctor's instructions and physiotherapeutic suggestions. Nonetheless, physiotherapists and sports doctors should remember about the very detailed rehabilitation instructions for the sportsman, but mainly the gradual rehabilitation trainings, specifically accordingly to the trained discipline (Sabo, 2013).

Equally serious problem, as the not fully treated injury, is the delayed beginning of the treatment. Quite common - especially among young sportsmen - is dissimulation (Thomas, Tarr, 2009). They do not reveal the troubling disorders, for fear of being excluded from the training, competition or for their position as a partner being diminished.

The main risk factor for injuries in ballroom dancing is its technique, paradoxically. Both, standard and LatinAmerican dances sometimes require non-anatomical moves, which define the technique level. Unfortunately, what is identified as dancing perfection, in fact, triggers a variety of traumas including the soft tissue deformation, dangerous strain of the tendons, ligaments, fascia and muscles and can finally lead to the habit which may cause arthritic changes in the future. Another risk factor predisposing to trauma is lack of training education course, and the resulting training errors. Next risk is frequent overtraining of sportsmen and training or attending a tournament right after injury, or in the state of extreme exhaustion. Performing sudden, quick moves, often jumps or even run on $7-9 \mathrm{~cm}$ high-heels (women ballroom dancers), is also not very safe. The injure risk rises together with psychological stress and depends as well on the technical conditions of the venue.

The aim of the paper was the evaluation of the influence of rehabilitation on health of the ballroom dancers after injuries.

The research issue was the attempt to answer the question: what is the influence of rehabilitation on the time of physical activity recovering to the physiological state.

\section{Methods}

In 2014 and 2015 ballroom dancers from all around Poland, who were rehabilitated after injuries resulting from training ballroom dancing, were examined. As many as 63 athletes, survey showed, were injured during their career. 
The questioned were professional dancers aged between 13 and 30 years old. In order to determine the influence of rehabilitation on dancers' health they were divided into two groups.

Tahle 2. Number of surveyed ballroom dancers, group I and II

\begin{tabular}{ccc}
\hline \multirow{2}{*}{ Group } & \multicolumn{2}{c}{ Number of dancers } \\
\cline { 2 - 3 } & $\mathrm{n}$ & $\%$ \\
\hline $\mathrm{I}$ & 47 & 75 \\
II & 16 & 25 \\
\hline Total & 63 & 100 \\
\hline
\end{tabular}

First group included 47 dancers whose rehabilitation took place in the rehabilitation centre under physiotherapeutic supervision. Second group consisted of 16 people who rehabilitated themselves on their own (Table 2). Statistical analysis showed no correlation between sex and age and link to particular group.

The opinion poll based on the survey was used as a test method. The questionnaire included closed and open questions which were to show the influence of injury and its treatment on future sports career. Questions were detailed and referred to kinds of injuries and their causes, the process of treatment, duration of rehabilitation, as well as its process and results.

The set of data was presented in graphs and tables. After collection of results the statistical analysis with the use of the Pearson's chi-squared test was conducted.

\section{Test resullts and their analysis}

Most of injuries happened during training (68\%), no matter if the warm-up was in place or not. Nonetheless, there are not many dancers who will go training without a warm-up, but if such situation occurs, it is rather an incident than negligence. Next reason for sports injuries were long-term overloads (16\%). Only $11 \%$ of the surveyed were injured during competition and only $5 \%$ during the warm-up (Table 3, Figure 1).

Table 3. Injuries in various situations of ballroom dancing

\begin{tabular}{lrc}
\hline \multirow{2}{*}{ Injury circumstance } & \multicolumn{2}{c}{ Numbers of injury } \\
\cline { 2 - 3 } & $\mathrm{n}$ & $\%$ \\
\hline Warp-up & 3 & 5 \\
Training & 43 & 68 \\
Long-term overload & 10 & 16 \\
Competition & 7 & 11 \\
\hline Total & 63 & 100 \\
\hline
\end{tabular}




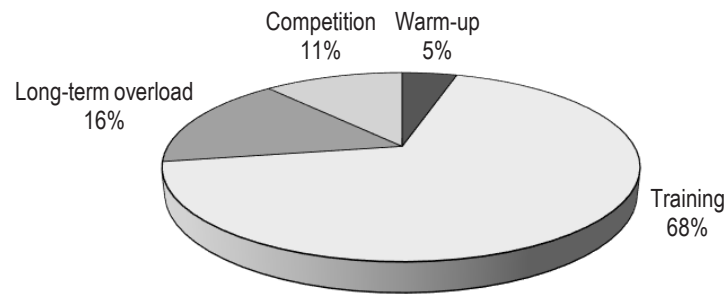

Figune 1. Injury circumstance

Lower limbs are the most prone to injuries in ballroom dancing, they constitute $47 \%$ of all injuries, spine injuries constitute $37 \%$ and upper limbs took the last place and were injured among $16 \%$ of the surveyed (Table 4, Figure 2).

Table 4. Various body parts injuries

\begin{tabular}{lcc}
\hline \multirow{2}{*}{ Injured body parts } & \multicolumn{2}{c}{ Number of injured dancers } \\
\cline { 2 - 3 } & $\mathrm{n}$ & $\%$ \\
\hline Lower limbs & 30 & 47 \\
Upper limbs & 10 & 16 \\
Spine & 23 & 37 \\
\hline Total & 63 & 100 \\
\hline
\end{tabular}

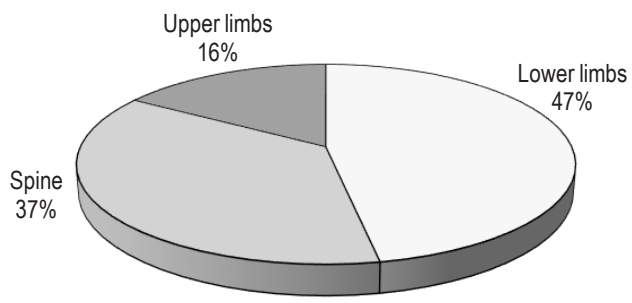

Figulle 2. Injured body parts

The most frequent, among the most severe sports injuries, were muscle traumas (25\%), rarely - bone traumas (22\%), next - ligaments and tendons injuries (18\% each), joint capsule injuries (12\%). Other, which constituted $5 \%$, were described as often not diagnosed or neurological (Table 5, Figure 3). 
Table 5. Injuries of ballroom dancers

\begin{tabular}{lcc}
\hline \multirow{2}{*}{ Tissues injured } & \multicolumn{2}{c}{ Dancers' injuries } \\
\cline { 2 - 3 } \multicolumn{1}{c}{ Muscles } & $\mathrm{n}$ & $\%$ \\
Bones & 16 & 25 \\
Tendons & 14 & 22 \\
Ligaments & 11 & 18 \\
Joint capsule & 11 & 18 \\
Other & 8 & 12 \\
\hline Total & 3 & 5 \\
\hline
\end{tabular}

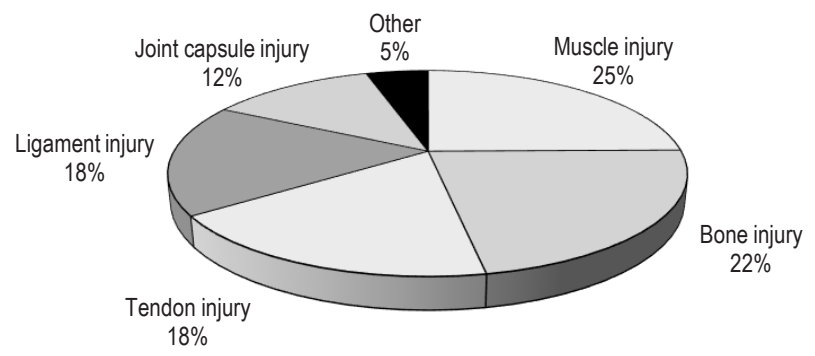

Figure 3. Tissues injured

Number of rehabilitation days varied according to the type of injury. Ligaments rehabilitation required the longest treatment. In the first group the average phase lasted 75 days and in the second as much as 120 days (Table 6). Such a considerable difference remained in each type of injury. Basing on this, it can be concluded that people not taking specialist treatment need more time to recuperate.

Table $\mathfrak{G}$. Average number of days of rehabilitation of dancers after injuries

\begin{tabular}{lccc}
\hline \multirow{2}{*}{ Type of injured tissues } & \multicolumn{2}{c}{$\begin{array}{c}\text { Average number of rehabilitation days } \\
\text { in particular group }\end{array}$} & $\begin{array}{c}\text { Average number of rehabilitation } \\
\text { days of all specific injuries }\end{array}$ \\
\cline { 2 - 3 } & \multicolumn{1}{c}{ I } & 30 & 22.0 \\
\hline Muscles & 14 & 56 & 45.5 \\
Bones & 35 & 30 & 22.0 \\
Tendons & 14 & 120 & 97.5 \\
Ligaments & 75 & 28 & 24.5 \\
Joint capsule & 21 & 21 & 18.5 \\
\hline Other & 16 & & \\
\hline
\end{tabular}


Unfortunately, seemingly small injuries are too often ignored and treated too long with the so called 'wellness' methods (Dziak, 2002). It leads to injuries being not fully treated and consequently - their frequent recurrence. Even $62,5 \%$ of self-treating dancers - often visiting charlatans who prey on their suffering-admit injury recurrence. In the group treated by specialists, only $15 \%$ suffered recurrence of ailments (Table 6).

The most frequent and common ways of coping with ailments include ointments and cryotherapy (Figure 4). Sportsmen often visit the masseur for help (some dance clubs have their own specialist, which facilitates and quickens the rehabilitation). Next, sportsmen employ physiotherapeutic treatments, take pharmaceuticals, and use kinesis therapy. When needed, the doctors use immobilisation and plaster casts. Fortunately, dancers rarely take steroids injections directly to joints, so called "blockages" which, in my opinion, act as a palliative only. Unluckily, there are cases when the operation is required. They refer mainly to spine and knee joint problems. Some of the surveyed supplemented the treatment with acupuncture, manual therapy, kinesio-taping, etc.

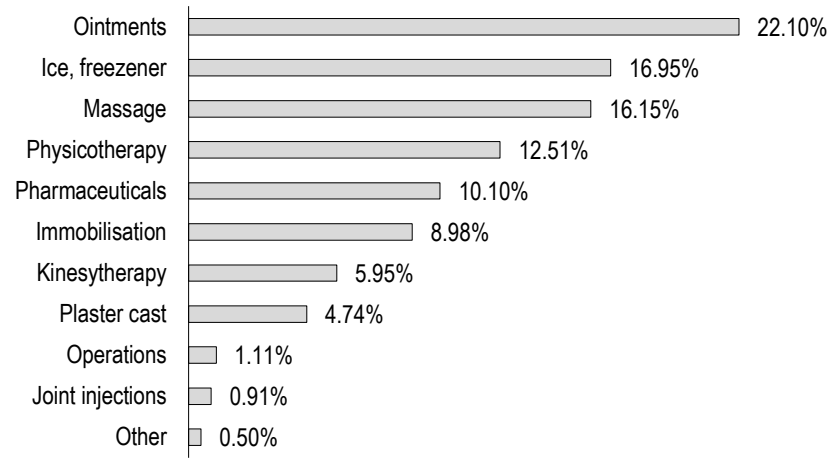

Figulpe 4. Methods of injury treatment

Often, quick restoration of the possibility of employing training and start loads from before the injury is impossible. Few self-rehabilitating people realise it. Complete recovery, before getting back on the floor, prevents severe injuries, which in $1 / 4$ cases originates from past problems (Table 7 ).

Table 7. Physical activity recovery of dancers after injuries

\begin{tabular}{lrrrrrr}
\hline \multirow{2}{*}{$\begin{array}{l}\text { Physical activity recovery } \\
\text { of dancers }\end{array}$} & \multicolumn{3}{c}{ Number of dancers in particular groups } & \multicolumn{2}{c}{ Total } \\
\cline { 2 - 6 } & $\mathrm{n}$ & $\%$ & $\mathrm{n}$ & $\%$ & $\mathrm{n}$ & $\%$ \\
\hline Complete & 41 & 65 & 9 & 14 & 50 & 79 \\
Partial & 6 & 10 & 4 & 6 & 10 & 16 \\
No recovery & 0 & 0 & 3 & 5 & 3 & 5 \\
\hline Total & 47 & 75 & 16 & 25 & 63 & 100 \\
\hline
\end{tabular}


In the first group all dancers got back to the right physical activity. Only six dancers recovered partially, others recuperated completely. Unfortunately, in the second group not all of the sportsmen returned to the physical activity, what is worse, three of the surveyed lost the functions irrevocably (Figure 5). The statistical analysis, with the use of the Pearson's chi-squared test showed the significant correlation between the recovery of physical activity and the group division.

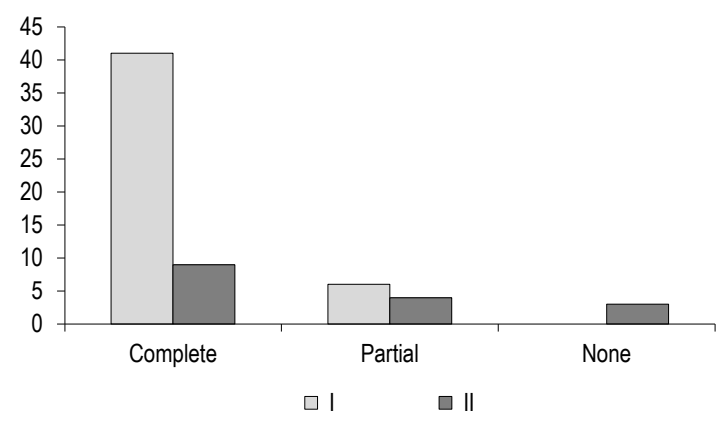

Figure 5. Level of physical activity recovery

\section{Conclusion}

1. Rehabilitation has positive influence on health of ballroom dancers after injuries.

2. Specialist rehabilitation shortens time of recuperation and boosts chances for complete recovery.

3. Physiotherapist rehabilitation at a good rehabilitation centre lowers the risk of reoccurrence of body injury of ballroom dancers.

\section{References}

Blecharz, J. (2009). Psychologiczne aspekty urazu fizycznego sportowca. Sport Wyczynowy, 531 (3), 77-87.

Dziak, A. (2002). Uszkodzenia sportowe i ich leczenie. Acta Clinica, 2 (3), 217-224.

Gawroński, W. (1998). Ice,Rice,Price... Medicina Sportiva, 2 (2), 183-184.

Heil, J. (1993). Psychology of Sport Injury. Champaign: Human Kinetics Publishers.

Kita, S.B. (2004). Typowe obrażenia ciała u sportowców. Medicina Sportiva, 8, Suppl. 1, 171-175.

Kłodecka-Różalska, J. (1996). Czynniki psychologiczne w zapobieganiu i rehabilitacji urazów sportowych. Sport Wyczynowy, 383-384 (11-12), 69-75.

Olex-Mierzejewska, D. (1996). Rola czynników psychicznych w powstawaniu urazowych obrażeń ciała u sportowców. Sport Wyczynowy, 375-376 (3-4), 53-57.

Sabo, M. (2013). Physical therapy rehabilitation strategies for dancers: a qualitative study. Journal of Dance Medicine \& Science, 17 (1), $11-17$.

Thomas, H., Tarr, J. (2009). Dancers' perceptions of pain and injury: positive and negative effects. Journal of Dance Medicine \& Science, $13(2), 51-59$.

Wanke, E.M., Mill, L., Wanke, A., Davenport, J., Checcetti, F., Koch, F., Groneberg, D.A. (2013). Dance partner or dance floor? Exogenous factors resulting in accidents in professional dancers. Medical problems of performing artists, 28 (3), 131-136. 
Wanke, E.M., Quarcoo, D., Uibel, S., Groneberg, D.A. (2012). Rehabilitation after occupational accidents in professional dancers: advice with due regard to dance specific aspects. Die Rehabilitation, 51 (4), 221-228.

Widuchowski, J., Widuchowski, W. (2005). Urazy i obrażenia narządu ruchu w sporcie. Medicina Sportiva, 9, Suppl. 4, $281-292$.

Cite this article aS: Banio A. (2016). Influence of Rehabilitation on Health of Ballroom Dancers after Sports Injuries. Central European Journal of Sport Sciences and Medicine, 14 (2), 63-71. DOI: 10.18276/cej.2016.2-07. 
